\title{
Dušan Coufal. Turnaj víry. Polemika o kalich na basilejském koncilu 1431-1433
}

(Studie a prameny k dějinám myšlení v českých zemích, sv. 20), Praha, Filosofia 2020, 652 s., ISBN 978-80-7007-620-0

Kniha je věnována krátkému období tř́ let v závěru husitských válek, kdy se rozhodovalo o dalším osudu Českého království: výklad se věnuje pozvání českých husitů na všeobecný církevní koncil v Basileji a učené disputaci mezi koncilními otci a reprezentanty husitského učení. Tematika knihy navazuje na řadu starších pokusů popsat průběh slyšení Čechů v Basileji a cestu k uzavření kompaktát. Všechny se spokojily sledováním diplomatických jednání a hlavních směrů učené disputace. D. Coufal šel do větší hloubky i šíře a rukopisným studiem odhalil řadu detailů, vazeb a souvislostí.

Kniha je členěna do sedmi kapitol s úvodem a závěrem a doplněna kromě obvyklého vybavení (seznamy pramenů a literatury) také ediční př́lohou. Text je nejen vysoce fundovaným výkladem složitých otázek z oblasti teologie, ale i čtivě napsaným vyprávěním o dějích ve vzrušené době. Všechna tvrzení jsou velmi pečlivě dokladována v bohatém poznámkovém aparátu.

Výklad je uvozen popisem situace kolem svolání koncilu, pokusu o jeho rozpuštění a role české otázky při obhajování existence koncilu proti papeži. Základní motiv (význam české kauzy pro zachování koncilu v činnosti) je znám už ze studie L. Hofmana. Autor knihy však postoupil dále. Provedl revizi pramenů, analyzoval detailně argumentaci koncilních činitelů, kteří se museli vyrovnat s problémem, ,jak lze s heretiky disputovat o tom, co již jednou bylo církevní instancí odsouzeno“, tedy jak se vyrovnat s dědictvím koncilu kostnického. Podrobností výkladu a hledáním souvislostí předčí Coufal jak práci Hofmana, tak novější studie k této otázce od F. Šmahela, J. Kejře a B. Kaňáka, u některých detailů pracoval paralelně s výzkumem Adama Pálky. ${ }^{1}$ To se týká jak popisu počátků koncilu, tak procesu pozvání Čechů do Basileje, kdy autor nachází i dosud opomíjené detaily. Zajímavým zjištěním je výrazný zájem Jana Rokycany o uskutečnění jednání, jeho kontakty s koncilními činiteli a snaha cestu do Basileje prosadit. Ač bychom se mohli domnívat, že pramenný komplex pro politiku doby husitské už je celý znám, i dnes se ještě nalézají nové prameny k tolikrát převyprávěným prríběhům. Dokazuje to i konvolut písemností z kanceláře Viléma Bavorského, uložený v Mnichově ve fondu bavorských kurfiřtů, který autor využil pro doplnění zpráv o vydávání glejtů členům delegací, stejně jako pečlivě uvádí řadu dalších opisů písemností známých ze starších edic.

Kromě Jana z Rokycan figuruje v knize také řada dalších osobností spojených s univerzitou - mistři a bakaláři, zapojení do basilejského dění (Ondřej ze Znojma, Petr ze Žatce, Mikuláš Biskupec z Pelhřrimova, Martin Lupáč, Prokop z Plzně i Angličan Petr Payne),

1 Adam PálKa, Husitské poselstvo, projev Pax vobis, šestice stručných vzpomínek. (Staro)nové poznatky k chebskému jednáni z května 1432, Český časopis historický 118, 2020, s. 7-43. 
mihnou se ale i starší mistři při retrospektivně probíraných otázkách (nutno uvést především Jakoubka ze Stř́ibra).

Kapitola věnovaná př́pravám koncilních teologů a rétorů na klání s husity se také neomezila na výčet hlavních témat a názorů. Autor se zaměřil na jednu ze čtyř diskutovaných otázek, totiž na artikul o laickém přijímání z kalicha - tím navázal na svoji první knihu věnovanou snahám husitů o uskutečnění učené disputace o laickém kalichu s katolickými učenci a vývoji užívaných argumentů na obranu i na odmítání kalicha. ${ }^{2}$ Tentokrát se Coufal soustředil na Ivana z Dubrovníku a jeho př́pravné texty, v nichž hledal odpovědi na otázky po zdrojích informací koncilních polemikủ. Nová zjištění přinesla také konfrontace př́ípravných textů koncilních řečníků s texty přednesenými při výsledném klání.

Št’astným spojením práce historika, paleografa, latiníka a teologa dokázal vytěžit z rukopisného bohatství řady evropských knihoven či archivů nová fakta nebo možné hypotézy. Př́nosem autora je tak nejen filiace textů, ale i sledování způsobu myšlení a argumentace koncilních teologů. Hledá díla, z nichž mohli čerpat znalosti o husitských názorech, užívaných autoritách atd. Jeho komplexní výzkum rukopisů si všímal i jejich původu, majitelů, doby vzniku, čímž mohl autor dospět i $\mathrm{k}$ závěrům o šiření textů do Basileje a možných predlohách pro polemiku. Práce proto svými objevy přispěla i oboru kodikologie a šiře pojatých dějin středověké vzdělanosti.

Z výkladu vystupuje mezi českými řečníky velmi výrazně úloha Jana Rokycany, a to nejen proto, že se věnoval otázce, která je ve středu pozornosti autora knihy, tedy kalichu. Výhledově hlavní a oficiální reprezentant utrakvistů se osvědčil jak v př́ípravné fázi, tak v průběhu jednání na koncilu a s koncilními legáty jako diplomat a taktik, který již na počátku třicátých let uvažoval v celozemském rozměru a zájmu, na rozdíl od dalších tř́i obhájců ostatních husitských artikulů.

Další kapitoly jsou pak věnovány popisu a výkladu hlavního střetu učenců na koncilu počínaje reakcí na př́jezd Čechů, přes učený souboj až po závěrečné dilema koncilního sboru: jak se postavit k českým požadavkům, jak naložit s myšlenkou návratu k přijímání podobojí. Na scénu vystupuje celá plejáda významných mužů své doby. Česká kauza se tak dostává do souvislosti působení celé řady vynikajících osobností tehdejší Evropy - u problému povolení laického kalicha se střetlo několik názorových směrů.

$\mathrm{Na}$ jedné straně vystupuje zástupce vídeňské univerzity T. Ebendorfer podporovaný Jindřichem Kalteisenem. Ti argumentovali proti poskytnutí ústupků Čechům a navrhovali poměrně idealistickou cestu celocírkevní reformy, jež by dodala sílu k potření husitské hereze. Tato vídeňská „klika“, jejíž působení nedávno detailně prostudovala Christina Traxlerová, ${ }^{3}$ se v Basileji střetla s jinými př́stupy. Skupina zformovaná kolem předsedy koncilu Juliána Cesariniho postupovala, soudí Coufal, podle předem promyšlené taktiky a plánu, který mu pomohl naplňovat především Mikuláš Kusánský a podporovaly jej argumentačně i další teologické veličiny jako Ivan z Dubrovníku a Heymeric de Campo. Vedle disputovaného materiálu si autor všímá i zákulisních jednání, která nakonec měla významnou váhu při výsledném uzavírání debaty.

2 Dušan Coufal, Polemika o kalich mezi teologií a politikou 1414-1431. Předpoklady basilejské disputace o prvním z pražských artikulü, Kalich, Praha 2012.

3 Christina Traxler, Firmiter velitis resistere. Die Auseinandersetzung der Wiener Universität mit dem Hussitismus vom Konstanzer Konzil (1414-1418) bis zum Beginn des Basler Konzils (1431-1449), Vienna University Press (Schriften des Archivs der Universität Wien, Bd. 27), Göttingen 2019, 547 s. 
K aktivitám vídeňské univerzity dodejme, že stoupaly teprve od r. 1429, kdy vídeňští mistři při jednáních s husity v Bratislavě spolupracovali s pařížskými učenci. Hlavní nasazení vídeňské Rudolfiny však přišlo až v době příprav a v průběhu basilejského koncilu. Zástupce vídeňské univerzity Thomas Ebendorfer se účastnil také jako člen koncilních legací jednání s husity, ale spolu s dalšími vídeňskými mistry představoval neústupné křídlo koncilních otců, kteří blokovali domluvu o kompaktátech. Asi také těžce nesl, že tvrdá linie vídeňské Rudolfiny nemá delší tradici a právě on začal vytvářet umělý obraz vídeňské univerzity jako aktivní bojovnice proti husitům od samého počátku střetu římské církve s nimi.

Vrat'me se ale k Turnaji víry. Výsledky výkladových kapitol shrnuje a hodnotí Coufal v obsažném závěru, zamýšlejícím se nad vítězi a poraženými. Na pouhých třech stranách je velmi zhuštěně, ale zcela výstižně shrnuto to nejpodstatnější, co kniha přináší. Znova pojmenovává cíle, které si uložili jednotliví hráči basilejského turnaje, a zamýšlí se nad výsledkem tohoto velkolepého střetnutí vybraných učenců své doby. Hodnocení výsledků nemůže být jednoznačné, protože ani jedna strana nedosáhla všeho. Tato minuciézní, vícebarevná (nikoli černobílá) úvaha, vážení motivů, taktik a výsledků patř́ k přednostem knihy a řadí ji vedle jiných pokusů o zasazení husitství do kontextu evropských dějin.

Autor zastavil svůj výklad v záŕí roku 1433, to je na prahu konečného jednání o kompaktáta. V této fázi proto vyznívá hodnocení spíše ve prospěch koncilu - Cesariniho cesta byla úspěšnější, ,husité na půdě protivníka ztráceli dech“. My ale víme, že události se odvíjely dále a dosažení kompaktátních smluv přinese zřejmě do hodnocení další odstín. Bude autor pokračovat a završí svoji husitskou trilogii obdobím 1433-1436? Pak teprve bude na místě soud o autorově hodnocení husitství.

Výkladový obsah knihy je doplněn menší ediční přílohou, která přináší sedm textů úřední i traktátové povahy. Nemá ambice být jejich definitivní kritickou edicí, nýbrž jen pomůckou pro výkladové partie zpř́stupněním textů, které dosud unikaly pozornosti. Nejsou proto vydány vždy v plném rozsahu nebo na základě úplné pramenné situace.

Coufalova druhá kniha přináší výsledky velmi rozsáhlého pramenného výzkumu, který zahrnul v širokém záběru traktátovou literaturu vztahující se k basilejskému turnaji víry. Autor provedl jejich interpretaci s důvtipem a znalostí souvislostí. Díky tomu se velmi prohloubil pohled na dění v Basileji počátkem 30. let 15. století. Dílo je značným přínosem pro medievistické bádání, a to nejen v rámci české historiografie.

\section{Roman Pazderský, Historik Wácslaw Wladiwoj Tomek a české dějepisectví 19. století, Praha, Archiv hlavního města Prahy - Nakladatelství Václav Žák - Casablanca 2020, 618 s., ISBN 978-80-86852-89-8}

Velké monografie věnované profilovým historikům se dají uchopit rozmanitým způsobem. Některý autor položí dưraz spíše na biografii než na vědecké dílo, jiný usiluje o proporční poměr mezi oběma složkami, další pak přistupuje k problematice komplexně 